Article

\title{
An Empirical Study on Distance Education and Job Match
}

\author{
Fengliang $\mathrm{Li}^{*}$ and Liang Wang \\ Institution of Education, Tsinghua University, Haidian District, Beijing 100084, China; wangliangnl@163.com \\ * Correspondence: dagger@tsinghua.edu.cn
}

Received: 24 November 2019; Accepted: 10 January 2020; Published: 15 January 2020

\begin{abstract}
Job match has always been the focus of educational research. However, current empirical studies are limited to the analysis of face-to-face education, and there's no empirical study focusing on the job match of distance education. To fill the gap in this research field, this study analyzes the distance learners in China to demonstrate the relationship between distance education and job match by using the data from a nationwide household survey. The empirical results involve two significant findings. Firstly, distance learners and face-to-face learners have no significant difference in job match. This study attempts to explain this with the human capital theory, that is, distance learners and face-to-face learners have no difference in obtaining their specific human capital, so they both prefer to work on a position characterized by job match. Secondly, job mismatch has no significant negative effect on the income of distance learners. This study attempts to explain this with the screening theory, that is, though distance education would improve the learners' specific human capital, it still acts as a diploma signal, to some extent, in China, thus making it impossible for the specific human capital obtained by distance learners to transform into a superiority in income.
\end{abstract}

Keywords: job match; distance education; income; specific human capital

\section{Introduction}

Distance education refers teaching and planned learning in which the teaching typically occurs in a different place from learning, requiring communication through technologies, as well as special institutional organization [1]. Distance education has a long history and involves a huge number of students. For example, in a study in 2013, there were more than 21 million distance education learners in developing countries alone [2]. In China alone, distance higher education operates on a huge scale to provide crucial support to China's move to make higher education more accessible to the populace [3]. At present, China's distance higher education only offers junior college and undergraduate programs. As of 2017, China's distance higher education had produced more than 1.78 million graduates in total, with the graduates receiving a junior college degree or a university degree through distance education representing much higher than $15 \%$ of the total number of junior college and university graduates in the same year. (Data from 2017 graduate statistics from China's national educational statistics network. University and junior college degrees are conferred in three ways: Regular institutions of higher learning, adult teaching, and online teaching. In 2017, a total of 11.606562 million graduates received their university and junior college degrees, with 177.7905 million (or 15\%) of them receiving their university and junior college degrees through online teaching. Adult teaching is increasingly using distance learning, so the total proportion of students in distance education is much higher than $15 \%$ ).

Compared with traditional face-to-face education, distance education has its distinct features. Most distance learners are adults with some working experience, and distance education is regarded as a low-grade form of education in many countries, especially in developing countries [4-8]. These features of distance education might affect the learner's employment. 
Surprisingly, though the job of a distance learner might be particular, and the number of graduates of distance higher education is so large, fewer empirical studies focus on the job of distance education learners. According to the employer assessment data for graduates of the Open University, UK, distance education helps learners gain high motivation and high coordination skills, etc. [9]. That said, studies have found that employers are seemingly not willing to recruit graduates of distance education [9-11].

Job match is an important proposition in the field of employment research. Job match refers to whether an individual is working on a job that matched his/her skills or education; if the work does not match his/her skills or education, it is called job mismatch [12,13]. A job match or mismatch will have effects on the job of a graduate. For example, studies have found that job mismatch will have a significant negative effect on the income of a traditional face-to-face learner [12-14]. By using the data of a household survey in China, this study will select laborers with a junior college degree and a university degree to make an empirical analysis of the job match of distance learners and demonstrate the relationship between distance education and job match, so as to fill the gap in this study area. This study seeks to explore two questions: Through a comparison with traditional face-to-face learners, (1) is job match more likely to happen for distance learners? And (2) does job mismatch have a significant negative effect on the income of a distance learner?

In the following sections, this paper will introduce the theories and literatures related to job match and describe the study design before presenting the hypotheses based on the data applied. Finally, the paper will present the results from the data analysis followed by a discussion with recommendations.

\section{Literature Review}

Many theories have attempted to explain job match. The human capital theory regards education as an important human capital, which can improve an individual's productivity, thus improving the individual's income [15]. Human capital is categorized into general and specific human capital, with the former applied in many jobs and the latter in specific jobs [16]. According to the human capital theory, professional learning helps learners gain specific human capital. Hence, when a learner fails to work in a job that does not match his/her learning, this results in the loss of specific human capital, and might lead to a decrease in his/her income [17].

Furthermore, when learners are trained in professional disciplines such as medical sciences and engineering, they gain more specific human capital, which increases their access to, and makes them more likely to choose, positions characterized by job match. Otherwise, they will suffer a greater loss of income [18].

The screening theory discusses the economic functions of education from the perspective of information asymmetry, emphasizing the signal and screening functions of education. It holds that learners seek more education to display their possession of high productivity to potential employers. Therefore, the function of education is more to distinguish and screen out the high-productivity people to make the best use of an individual's skills. As such, education has a strong signal function [19]. In accordance with the screening theory, there should be no difference of productivity (i.e., no difference of income) between workers with major-job match and those with major-job mismatch [17].

Many studies in the literature have examined the issue of job match, mainly covering two areas. The first involves the factors that significantly affect an individual's job match and the second, the relationship between job match and income. For example, Boudarbat and Chernoff found that demographic (e.g., sex) and socioeconomic characteristics (e.g., family background) have no significant effect on the job match of an individual [20]. On the other hand, an individual's level of educational attainment, academic records, and specialized major, (e.g., "Health Sciences") among other considerations, will significantly increase the probability that he/she will work on a position characterized by job match. This observation was shared by other studies that found learners' choice of subject disciplines that contained more specific human capital to have a significantly higher probability of experiencing job match $[12,13,21,22]$. 
Other studies have focused on the influence of job match on an individual's income. Neuman and Ziderman found a $10 \%$ increase in income among graduates of vocational education in Israel, compared to their peers who graduated with qualifications in general education [14]. However, no significant difference in income was found for graduates with job-mismatch, regardless of their training. Grubb studied the labor market of university graduates in the US and found that job match had brought higher income for those who graduated with both Baccalaureate and Sub-Baccalaureate degrees had greater income [23]. In Egypt, Arabsheibani found that graduates of medical sciences, sciences, and social sciences, could significantly improve their starting salary with job match, lending support to the finding that majors with a higher degree of specialization had a greater effect on improving one's income, with medical sciences leading the way, followed by sciences, and social sciences [18].

However, there are studies that suggest that job mismatch would not necessarily reduce one's income. Chung found that, when the job industry was controlled, graduates who experienced job-mismatch in Hong Kong did not experience a significant decrease in their income [24]. In Australia, Miller and Volker found that the starting salary of graduates of economics was no different from those in the sciences even though the former were not working jobs related to economics [25]. This was supported by Li, Ding, and Morgan who examined the labor market in China and found that only male graduates of engineering enjoyed higher starting salaries resulting from job match while graduates of other majors, both male and female, did not [26].

Although many studies have found that learners of highly specialized majors enjoy a greater probability of job match and that job match could significantly improve an individual's starting salary or income, it appears that research on job match has not reached a consensus, as the conclusions and findings are hybrid.

Furthermore, many studies in the literature, including those mentioned above, focused on the face-to-face learners, with little evidence discussing the job match of distance education learners. It can be found from the history of distance education, however, that distance education plays an important role in the development of the higher education of many countries [2,27].

At present, the majority of studies on job match have addressed the face-to-face learners. This presents an incomplete picture of the research topic given the huge proportion of distance education learners in higher education. In face-to-face education research, job match has a positive effect on individuals [28]. Furthermore, job characteristics have a significant relationship between attitudes towards distance education [29]. So, it is necessary to explore the relationship between job matching and distance education. This study will focus on the relationship between distance education and job match as well as the effect of job match on the income of distance learners. This study explores the job match of distance education learners, and the results hold the potential to help scholars and policy makers understand the role of and importance of distance education as a viable study mode for tertiary education.

\section{Research Design and Data}

\subsection{Research Hypothesis}

In accordance with the human capital theory, distance learners and face-to-face learners should have no significant difference in the human capital obtained if they have met the graduation requirements. Pursuant to this logic, distance learners will obtain as much specific human capital as face-to-face learners as long as they have graduated with relevant majors in their courses of study. Therefore, face-to-face learners and distance learners should experience equal opportunity to obtain a job match in the labor market. However, this is predicated on the assumption that distance learners, as well as face-to-face learners, could obtain specific human capital in equal measure.

However, if distance learners obtain less specific human capital than face-to-face learners, they will be more likely to experience job mismatch. It is generally known that in many developing countries, distance education is regarded as inferior in quality to face-to-face education $[4,5,7,8]$. For this 
reason, distance learners will have a significantly higher probability of being assigned to a position characterized by job mismatch than traditional face-to-face learners regardless of the majors in which the former have graduated in.

Therefore, the teaching quality and effect of distance education on the learners' job match can be examined through the extent to which distance education would significantly increase the probability of an individual experiencing job mismatch. In case the teaching quality and effect of distance education on learners' job match is as good as that of face-to-face education, learners will obtain as much specific human capital as face-to-face learners. Then, distance learners and face-to-face learners should have no significant difference in the probability of job match. On the contrary, if the teaching quality and effect of distance learning on learners' job match is more inferior, distance learners will obtain less specific human capital and suffer a significantly lower probability of job match.

This study will use data from China's labor market and be guided by the specific human capital framework, which has been used in previous research to explain China's distance higher education [30]. In addition, this study will use learners' satisfaction with distance learning to measure their perception of quality in distance education [31]. As a result, this paper expects that face-to-face learners and distance learners in China could obtain the same amount of specific human capital. From here, the first hypothesis was formulated for this study.

Hypothesis 1. No significant differences in job match probability would be found for distance education learners and face-to-face learners.

According to the human capital, job mismatch will have a significant negative effect on an individual's income. According to the screening theory, job mismatch will not significantly pull down individuals' income. However, some studies have found that job mismatch will have a significant effect on the income of face-to-face learners, and will reduce an individual's job satisfaction and working enthusiasm [32-34]. As job match in face-to-face education has a positive driving effect on an individual's income $[33,35,36]$, this study presents the second hypothesis:

Hypothesis 2. Job match would also have a significant positive effect on the income of distance learners.

It is important to note that, though there are different theories addressing job match, this study makes an empirical analysis for distance learners' job match, not for the purpose of verifying the relative greater explanatory power of a theory. Rather, this study intends to refer to relevant theories and analytical frameworks to empirically analyze whether distance education is an influential factor for job match, and whether job match will affect the income of distance learners, so as to fill the gap of distance education in this study area.

\subsection{Data Source}

Data for this study were taken from the Chinese Family Panel Studies (CFPS2014), a national comprehensive household survey administered by the Institute of Social Science Survey (ISSS), Peking University in 2014. (The website of CFPS: http://opendata.pku.edu.cn/dataverse/CFPS) This data is free and accessible to anyone by application. The data of the CFPS were obtained using a strict sampling design and is representative nationally.

The CPFS2014 consists of 37,147 valid adult samples in total and measuring variables, such as the highest level of educational attainment, mode of education, major, job code, income, sex, age, job characteristics (including industry and staff size of the organization served), and the residential region of individuals.

The mode of education may indicate whether a sample received his/her academic credential through face-to-face learning or distance learning. Namely, "distance education" is a dummy variable. If an individual received his/her highest degree through face-to-face education, "distance education" is assigned a value of 0 . Otherwise, it is assigned a value of 1 . 
Job match refers to whether an individual is working on a job that matched his/her skills or education $[12,13,21]$. Using the major and job code, together with other job characteristics, this study was able to assess the job match status of the sample. The match of major with job is assigned a value of 1 , and mismatch, 0 . When determining job match or mismatch, this study discusses each sample in a manner of panel discussion. Value assignment only follows the consensus reached by the panelists. Together with distance education and job match, income was used to assess the influence of job match on the income of distance learners by controlling other variables.

In this study, an empirical analysis was carried out for individuals who had received their academic credentials through distance learning in China. However, only academic credentials at the university and junior college levels are awarded through distance learning. Accordingly, this study only included participants whose highest educational level was a university degree or junior college diploma. The total number of sample cases at undergraduate or junior college levels were 967 . After deleting sample cases with missing values of the mode of education, major, and job code, 876 cases were selected for data analysis. Through the analysis of the 876 cases, the study found that the average age of distance learners was higher than that of face-to-face learners. The proportion of distance learners with work experience was also higher than that of face-to-face learners. These findings highlight the characteristics of distance education.

\section{Method}

In this study, a probit model with stepwise regression was employed for data analysis. This model is ideal in cases where the dependent variable is a dummy variable and the function is subject to normal distribution [37]. In the probit model, the core variable is the dummy variable of distance education. Taking reference from previous studies, a series of control variables were introduced into the model: Gender, age, urban or rural area, no working experience during learning (with samples having working experience as the control group), university degree (with samples holding a junior college degree as the control group), a dummy variable of different majors, industry, public sectors (with samples in private sectors as the control group), and the staff size of the organization served.

This study will apply the function of semi-logarithm to test Hypothesis 2, which is extensively applied in the field of economics to explore the influence of education on an individual's income [25]. A semi-logarithm function is used to get the natural logarithm of an individual's income as a dependent variable, while independent variables are not expressed with a logarithm. It is thus clear that the dependent variable in Hypothesis 2 is a continuous variable. Hence, this study will use multiple linear regression for analysis.

In the multiple linear regression, job match is a core independent variable used for analyzing whether job match could significantly increase an individual's income. In already existing studies, the independent variable, as one of the influential factors for income, typically consists of an individual's educational background, work experience, and the square of work experience, among others. In a specific study, work experience and its square are often replaced with an individual's age and its square [38]. This study will also include these variables and control variables mentioned in Hypothesis 1 in the multiple linear regression equation, and will exclude any eventually insignificant control variables using the stepwise regression method. This study will analyze the influence of job match on the income of face-to-face learners and distance learners, respectively. Table 1 is a brief statistical description of all the core variables in this study.

Table 1. A brief statistical description of the core variables.

\begin{tabular}{cccc}
\hline Name of Variable & Mean & Standard Deviation & Sample Size \\
\hline Distance education & 0.25 & 0.43 & 876 \\
Job match & 0.52 & 0.50 & 876 \\
University degree & 0.42 & 0.49 & 876 \\
Natural logarithm of income & 10.13 & 0.98 & 730 \\
\hline
\end{tabular}




\section{Empirical Results}

Hypothesis 1 mainly explores the influence of distance education on job match. The dependent variable is a dummy variable of job match, using the probit model. The core independent variable is "distance education", also a dummy one, with face-to-face learners as its control group. In the stepwise regression analysis, this study always controls the core independent variable ("distance education") within the regression equation, with other control variables to be subject to stepwise regression analysis.

Table 2 shows the regression result of the probit model. From Table 2, the coefficient of "distance education" is negative, but not significant. This indicates that when other factors are controlled, distance learners are more likely to suffer job mismatch than face-to-face learners; although, this difference is not statistically significant. This supports Hypothesis 1 in this study. Such an empirical result shows that, in China, distance learners can obtain as much specific human capital as face-to-face learners, which is consistent with the previous empirical finding that distance learners have the same educational satisfaction as face-to-face learners [31].

Table 2. Analysis of influential factors in job match.

\begin{tabular}{|c|c|c|}
\hline Independent Variable & Coefficient & Standard Error \\
\hline Distance education & -0.05 & 0.13 \\
\hline No working experience during learning & $-0.23 *$ & 0.11 \\
\hline Age & $-0.01 *$ & 0.006 \\
\hline Economics & $2.99 * * *$ & 0.37 \\
\hline Science of law & $2.42 * * *$ & 0.45 \\
\hline Education & $3.15^{* * *}$ & 0.39 \\
\hline Sciences & $2.12 * * *$ & 0.39 \\
\hline Engineering & $3.05 * * *$ & 0.36 \\
\hline Agricultural science & $1.58^{* * *}$ & 0.49 \\
\hline Medical science & $3.18^{* * *}$ & 0.39 \\
\hline Management & $3.30 * * *$ & 0.37 \\
\hline Constant term & $-2.09 * * *$ & 0.40 \\
\hline Pseudo $R^{2}$ & \multicolumn{2}{|c|}{0.31} \\
\hline $\mathrm{N}$ & \multicolumn{2}{|c|}{876} \\
\hline
\end{tabular}

Table 2 also shows that variables such as having "no working experience during learning", "age", and the dummy variables of some majors also significantly affect the job match of individuals. The coefficient of "no working experience during learning" is significantly negative, indicating that individuals with work experience during their schooling years are more likely to work in a position characterized by job match than those having no work experience during learning. work experience means a greater familiarity with the labor market, making it is easier to find a job characterized by job match. After other factors are controlled, job match shows a significant negative correlation to age, suggesting that age has a direct impact on an individual's job mismatch.

In terms of majors, graduates of economics, management, science of law, education, sciences, engineering, agricultural sciences, and medical sciences are more likely to experience job match than those in philosophy, literature, history, and other majors, consistent with existing empirical findings showing that graduates in a major containing more specific human capital have significantly higher probability to experience job match [12,13,20-22]. In addition, the university degree is not included in the final regression equation, showing that the level of educational attainment would not significantly affect the probability of job match.

Table 3 shows the multiple linear regression results of job match and an individual's income. From Column 1, the coefficient of "job match" is significantly positive, indicating that, for face-to-face learners, when other factors are controlled, job match has a positive income effect. However, the result of Column 2 reveals that the coefficient of "job match" is not significant. This suggests that, for distance learners, after other factors are controlled, the income effect of job match is not significant. This rejects 
Hypothesis 2 in this study. What needs to be explained here is that this paper tried to add relevant variables of the labor market (staff size of the organization, industry, and sector) to the regression equation; however, these variables did not enter the final stepwise regression equation, meaning that the labor market status does not change the final empirical results.

Table 3. Multiple linear regression of job match and individual income.

\begin{tabular}{ccc}
\hline Independent Variable & Column 1 Face-to-Face Learners & Column 2 Distance Learners \\
\hline Age & $0.29^{* * *}(0.03)$ & $0.11^{* * *}(0.04)$ \\
\hline Square of age & $-0.003^{* * *}(0.0004)$ & $-0.001^{*}(0.0006)$ \\
\hline Job match & $0.20^{* * *}(0.07)$ & $-0.07(0.12)$ \\
\hline University degree & - & $0.38^{* * *}(0.13)$ \\
\hline No working experience during learning & - & $-0.30^{* *}(0.12)$ \\
\hline Constant term & $4.62^{* * *}(0.53)$ & $7.78^{* * *}(0.75)$ \\
\hline Adj- $\mathrm{R}^{2}$ & 0.20 & 0.26 \\
\hline $\mathrm{N}$ & 547 & 183 \\
\hline
\end{tabular}

The dependent variable is the natural logarithm of an individual's income. The value in brackets is a standard error.

“**** means $p<1 \%$, “**” means $p<5 \%$, “*” means $p<10 \%$.

Certainly, it is important that this study does not to infer the causality among distance education, job match, and income, but it is also important to reveal the statistical relationship among them. The final empirical results support Hypothesis 1 and reject Hypothesis 2; that is, the empirical results reveal that distance learners and face-to-face learners have no significant difference in job match, and job match does not significantly increase a distance learner's income.

\section{Discussion}

In this study, Hypothesis 1 was supported, suggesting that the mode of study (distance learners or face-to-face learners) has no significant difference in job match. In addition, the results of this study provide support to the human capital theory, which posits that, since there is no difference between distance learners and face-to-face learners in obtaining their specific human capital, both types of learners would prefer to work in positions characterized by job match instead. Hypothesis 2 was not supported, suggesting that distance education in China was equally efficient in producing graduates who are comparatively just as productive as those who had completed their degrees via the traditional face-to-face courses. As such, distance learners would not suffer a significant decline in their income even if they were to work in a position characterized by job mismatch.

In recent years, debates on human capital theory and screening theory have focused on the relevance of job match in assessing the effectiveness of education on job search. This study provides empirical support for the validity of the human capital theory and screening theory through the study of distance education and job match. However, due to the inability to make a causal inference in this study, it could not account for the lack of significant differences between distance and face-to-face learners on the probability of working on a position characterized by job match, nor could it account for why the effect of job match on an individual distance learner's income was not significant. Future research could delve into the relationship between distance education and job match. In addition, the results of this study could only represent a Chinese sample; thus, it would be useful and informative to have comparative studies involving participants from different countries and regions in future research.

\section{Conclusions}

Since the 1980s, research on job match has been the focus of educational research. Existing empirical studies have mainly addressed the influential factors of job match as well as the influence of job match on an individual's working enthusiasm, productivity, and income. However, current 
empirical studies are limited to the analysis of face-to-face education, often ignoring the role of distance education in generating graduates for the job market. This study tested two hypotheses using nation-wide household survey data.

Two significant findings were found in this study. First, no difference was found in job match between distance learners and face-to-face learners. Second, job mismatch would not have a significant negative effect on the income of distance learners. Based on the above empirical findings, this study attempts to make the following recommendations on the future development of distance education:

Firstly, distance education should be promoted as a viable option for tertiary study. This notion has been supported in recent literature, which suggests that distance education possesses qualities comparable to face-to-face education. The empirical results demonstrate the convergence between face-to-face and distance education since distance learners have the same probability of job mismatch with face-to-face learners, which means that, in China, distance learners can obtain as much specific human capital as face-to-face learners. Unfortunately, distance education is still regarded as an inferior form of education in many developed countries. It is hoped that the growing popularity of MOOCs (Massive Open Online Courses) and OER (Open Educational Resource) worldwide would act as catalysts to the acceptance and enhancement of distance learning in the years to come. Secondly, providers of distance education shall collect the distance learners' behaviors in the labor market so as to improve distance education [39]. Finally, providers of distance education shall strive to improve the learners' specific human capital, and enable the distance learners' specific human capital to increase their income effectively in the labor market, which would result in distance learning being seen as a viable choice for future learners.

Author Contributions: Both authors have contributed to literature review, data analysis, writing and editing. All authors have read and agreed to the published version of the manuscript.

Funding: This research received no external funding.

Acknowledgments: The authors would like to acknowledge Timothy Teo, Liang-Cheng Zhang and two of anonymous reviewers for their useful comments and suggestions.

Conflicts of Interest: The authors declare no conflict of interest.

\section{References}

1. Moore, M.G.; Kearsley, G. Distance Education: A Systems View of Online Learning, 3rd ed.; Wadsworth Cengage Learning: Belmont, CA, USA, 2012.

2. Bates, T. Is There a Future for Distance Education? Online Learning and Distance Education Resources. 2013. Available online: http://www.tonybates.ca/2013/10/23/is-there-a-future-for-distance-education (accessed on 15 February 2019).

3. Li, F.; Zhou, M.; Fan, B. Can Distance Education Increase Educational Equality?-Evidence from the Expansion of Chinese Higher Education. Stud. High. Educ. 2014, 39, 1811-1822. [CrossRef]

4. Noble, D. Digital diploma mills: The automation of higher education. First Monday. 1998, 7, 355-368.

5. Robertson, H.J. No More Teachers, No More Books: The Commercialization of Canadian Schools; McLelland \& Stewart: Toronto, ON, Canada, 1998.

6. Latchem, C.; Özkul, A.E.; Aydin, C.H.; Mutlu, M.E. The open education system, Anadolu University, Turkey: E-transformation in a mega-university. Open Learn. 2006, 21, 221-235. [CrossRef]

7. Laaser, W. Virtual universities for African and Arab countries. Turk. Online J. Distance Educ. 2006, 7, 147-160.

8. Chen, L.; Wang, N. Attitudes to Distance Education in China. In Distance Education Technologies in Asia; Baggaley, J., Belawati, T., Eds.; International Development Research Centre: Ottawa, ON, Canada, 2010; pp. 111-126.

9. Gaskell, A.; Mills, R. Challenges for Distance Education and e-Learning: Quality Acceptability and Outcomes. Distance Educ. China 2015, 2015, 5-15.

10. Columbaro, N.L.; Monaghan, C.H. Employers Perceptions of Online Degrees: A Literature Review. Online J. Distance Learn. Adm. 2009, 12, 2-11. 
11. Deming, D.; Yuchtman, N.; Abulafi, A.; Goldin, C.; Katz, L. The Value of Postsecondary Credentials in the Labor Market: An Experimental Study. Am. Econ. Rev. 2016, 106, 778-806. [CrossRef]

12. Robst, J. Education and job match: The relatedness of college major and work. Econ. Educ. Rev. 2007, 26, 397-407. [CrossRef]

13. Robst, J. Education, College Major, and Job Match: Gender Differences in Reasons for Mismatch. Educ. Econ. 2007, 15, 159-175. [CrossRef]

14. Neuman, S.; Ziderman, A. Vocational Schooling, Occupational Matching, and Labor Market Earnings in Israel. J. Hum. Resour. 1991, 26, 256-281. [CrossRef]

15. Schultz, T.W. Investment in Human Capital. Am. Econ. Rev. 1961, 51, 1-17.

16. Becker, G.S. Human Capita: A Theoretical and Empirical Analysis, with Special Reference to Education, 3rd ed.; The University of Chicago Press: Chicago, IL, USA, 1964.

17. Wiles, P. The correlation between education and earnings: The external-test-not-content hypothesis (ETNC). High. Educ. 1974, 3, 43-58. [CrossRef]

18. Arabsheibani, G. The Wiles Test revisited. Econ. Lett. 1989, 29, 361-364. [CrossRef]

19. Spence, M. Job market signaling. Q. J. Econ. 1973, 87, 355-374. [CrossRef]

20. Boudarbat, B.; Chernoff, V. The Determinants of Education-Job Match among Canadian University Graduates. IZA Discussion Paper, No. 4513. Available online: http://www.iza.org/en/webcontent/publications/papers/ viewAbstract?dp_id=4513 (accessed on 12 May 2019).

21. Heijke, H.; Meng, C.; Ris, C. Fitting to the job: The role of generic and vocational competencies in adjustment and performance. Labour Econ. 2003, 10, 215-229. [CrossRef]

22. Lv, Y.; Lv, J.; Zhong, S. Analysis on Factors Impacting Matching between Learning and Application of Higher Vocational School Graduates. Vocat. Tech. Educ. 2012, 33, 34-38.

23. Grubb, W.N. The returns to education in the sub-baccalaureate labor market. Econ. Educ. Rev. 1997, 16, 231-245. [CrossRef]

24. Chung, Y. Educated mis-employment in Hong Kong: Earnings effects of employment in unmatched fields of work. Econ. Educ. Rev. 1990, 9, 343-350. [CrossRef]

25. Miller, P.W.; Volker, P.A. The screening hypothesis: An application of the Wiles Test. Econ. Inq. 1984, 22, 121-127. [CrossRef]

26. Li, F.; Ding, X.; Morgan, W.J. Higher Education and the Starting Wages of Graduates in China. Int. J. Educ. Dev. 2009, 29, 374-381.

27. Casey, D.M. The historical development of distance education through technology. TechTrends 2008, 52, 45-51.

28. Sorensen, A.; Kalleberg, A. An Outline of a Theory of the Matching of Persons to Jobs. In Sociological Perspectives on Labour Markets; Berg, I.E., Ed.; Academic Press: New York, NY, USA, 1981.

29. Lin, X.F.; Liang, J.C.; Tsai, C.C.; Hu, Q. The moderating role of self-regulated learning in job characteristics and attitudes towards web-based continuing learning in the airlines workplace. Australas. J. Educ. Technol. 2018, 34, 102-115. [CrossRef]

30. Li, F.; Zhang, X.; Zhang, S. Who will Pay for Distance Education: An Empirical Study from the Angle of General Training and Specific Training. Mod. Distance Educ. Res. 2010, 4, 20-26. Available online: http://www.cqvip.com/Main/Detail.aspx?id=34445413 (accessed on 15 January 2020).

31. Li, F.; Sun, Y.; Xie, K. Can Distance Learners Enjoy the Cost Advantage? Mod. Distance Educ. Res. 2013, 3, 61-65.

32. Garcia-Espejo, I.; Ibanez, M. Educational-Skill Matches and Labour Achievements among Graduates in Spain. Eur. Sociol. Rev. 2006, 22, 141-156. [CrossRef]

33. Roterman, M.L. Is there a Value in an Arts Education? An Analysis Using the 1997 National Graduates Survey. Master's Thesis, University of Guelph, Guelph, ON, Canada, 1999.

34. Allen, J.; Weert, E.D. What do Educational Mismatches Tell us about Skills Mismatches? A Cross-country Analysis. Eur. J. Educ. 2007, 42, 59-73. [CrossRef]

35. Wolbers, M. Job Mismatches and their Labour-Market Effects among School-Leavers in Europe. Eur. Sociol. Rev. 2003, 19, 249-266. [CrossRef]

36. Xu, X.; Yue, C.; Xu, R. Influencing Factors and Starting Salary Effects of Match between College Graduates' Majors and Job. Educ. Res. Mon. 2018, 19, 249-266.

37. Li, F.; Li, Y.; Zhang, S. The improve effect of distance Education on personal income: From the Perspective of Urban and Rural areas and gender. E-Educ. Res. 2015, 36, 49-54. 
38. Heckman, J.; Lochner, L.; Todd, P. Fifty Years of Mincer Earnings Regressions; NBER Working Paper No. 9732; National Bureau of Economic Research: Cambridge, MA, USA, 2003; Available online: https://www.nber. org/papers/w9732.pdf (accessed on 15 May 2019).

39. Andrews, T.; Tynan, B. Distance learners: Connected, mobile and resourceful individuals. Australas. J. Educ. Technol. 2012, 28, 565-579. [CrossRef] 